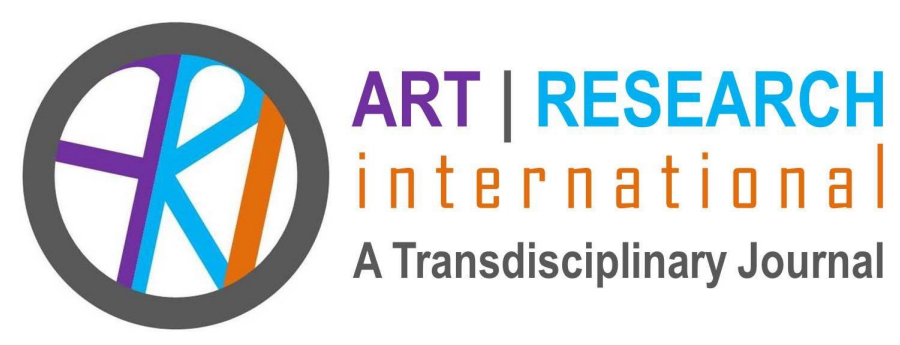

\title{
RECUPERATING CONFLICT: BETWEEN CRITICAL GENEROSITY AND ANTAGONISTIC ACTIVATION
}

\section{Emily Carr University of Art and Design \\ jlanglois@ecuad.ca}

Justin Langlois is an artist, educator, and organizer. His practice explores collaborative structures, critical pedagogy, and infrastructural frameworks. He is currently the Associate Dean of the Master of Fine Arts program at Emily Carr University of Art and Design and lives as an uninvited guest on unceded Coast Salish Territory.

Abstract: In this paper, I will argue that small scale conflict and disagreement in civic life are a vernacular part of our social experience and yet, in the hands of artists, they can actively work against larger hegemonic structures and help foster new expressions of agency and democratic action. By examining a number of socially engaged art projects I developed as the research director of the artist collective, Broken City Lab, and by situating this work in relation to a number of core ideas exploring notions of antagonism, I propose a tactical recuperation of the idea of conflict in order to see it as a core part of our democratic social lives.

Keywords: social practice; antagonism; conflict; artist residencies; collaboration; collectivism 


\section{On Being Difficult}

"You're making things harder than they need to be."

The phrase above may sound familiar. While it reads like a declarative observation, it actually feels like a tacit demand. Stop what you're doing. This isn't right. Why are you doing it that way? An artist might respond in one of a couple of ways. They may feel misunderstood, annoyed that what they see as a very necessary, if complex, process is being interpreted as something excessive, foolhardy, or even indulgent, or, perhaps they feel a tinge of pride, happy to be working against expectations, slowing things down, and treating the very idea of difficulty as something worthy of study. In my own artistic practice, I know it is often somewhere in between.

As artists, our efforts to explore new ways of being together in the world is an essential part of any creative practice and the foundation of socially engaged art (Helguera, 2011). In socially engaged art, rather than material transformation, it is about the transformation of how we can be together and where we can be in common. This practice of transformation is necessary to unpack because it is not always straightforward. Transformation is often driven by the need to address a conflict. Things change when the status quo is overturned. However, social transformation, whether in the places we live or the communities we are a part of, has to account for the catalyzing potential of disagreement or conflict (Miessen, 2010) because it is an inevitable part of the process. My idea of transformation may not be the same as yours, or, it might even be antithetical to it. However, that difference, or more precisely, the ability to host that difference in our social lives is the foundation of a healthy democracy. ${ }^{1}$ That means that disagreement is not something we should avoid; it is something we need to cultivate.

It is not just that conflict and disagreement are such a core part of our social experiences, they also actively work against larger hegemonic narratives of how we should conduct ourselves in the world (Banaji, 2008). Smooth transactions and seamless experiences are most attractive to those who already hold power. Unfortunately, our shorthand understanding of conflict has been stretched out of shape, oversimplified, and distorted into a concept that translates into one side destroying another, full-on violence, or outright war. This narrow definition does not serve the interests of social transformation. It does not capture important political actions based on conflict and disagreement such as protest or creative resistance, which aim to activate public discourse and civic action around an issue. A healthy democracy is built on a plurality of perspectives and ways of living that necessarily bump into each other (Maloney \& Miller, 2008). So, we need to recuperate the idea of conflict in order to see it as a core part of our democratic social lives, as messy as they may be. To do that, we need to stop thinking about conflict as something that is "in the way" or inconvenient or making things harder than they need to be. Conflict is not something that 
stops us from getting things done. On the contrary, it is the very first step for how we start moving forward.

In their dynamic series of essays from 2013, The Undercommons: Fugitive Planning \& Black Study, the poet and professor of performance studies, poetics, and literary theory, Fred Moten, and autonomist and postcolonial theorist, Stefano Harney, discuss a "general antagonism" as public life (Harney \& Moten, 2013). Thirty years ago, Ernesto Laclau and Chantal Mouffe wrote about radical democracy as being premised on a constant exchange of tempered conflictual tendencies in their book, Hegemony and Socialist Strategy (Laclau \& Mouffe, 2014). And in the 1930s, the imprisoned political theorist, Antonio Gramsci, saw antagonism and conflict in class struggle as a way to build revolutionary politics (Gramsci, 1971). For each of them, ${ }^{2}$ conflict was not something to be silenced or solved. It is, instead, something to be cultivated, rehearsed, and tuned.

Towards that cultivation of conflict, our ability to act freely in the world and respond to it in real-time is a measure of our agency. To tackle the inevitable asymmetry of power that so often forms the foundation of injustice, we have to channel our creativity and agency in new and unexpected ways. From nascent community action groups to large-scale social movements and protests, if conflict and antagonism are the kindling, our agency is the spark. The fires that ensue are sometimes enormous and ferocious blazes (such as the ongoing protests in Hong Kong) ${ }^{3}$ while at other times they are numerous and slow-burning (such as Extinction Rebellion's continued public interventions). ${ }^{4}$ However, there are other registers of creative action that are also driven by a sense of antagonism, and as artists we can explore these registers through symbolic and poetic forms.

\section{Agency as Modulation, Art as Intervention}

In my practice, as an artist and educator, I look at how we can deploy our agency as a potent modulator of the social and political dynamics around us. It is important to note that modulation is not necessarily the same as outright transformation. It is also not infinite; it cannot go on forever in any single direction. Modulation is a momentary change in the pattern: It moves back and forth, increasing and decreasing its intervals of change, and amplifying and reducing the volume of activity. That modulation can be read as conflict or as an antagonism towards a baseline. Small actions and projects could be a short kind of modulation; larger social movements could be seen as a sustained wave. I want to suggest that in thinking about conflict as a modulation from an existing position, we can see it as a generative change, not something to work around.

In 2008, I founded the artist collective, Broken City Lab ${ }^{5}$ with Danielle Sabelli. We were both in graduate school, living in Windsor, Ontario, and seeing the city changing before our eyes. Our friends were moving to larger cities because there were no opportunities locally. The city was hemorrhaging blue-collar jobs that had been the economic backbone of 
the region for decades. Storefronts were empty, and public spaces were quietly falling into disrepair and disuse. Windsor had so much potential, but it was also a hard place to love. We found ourselves at the start of a modulation in our relationship to the city.

We started to wonder what stake we had in where we lived. We imagined Windsor as a case study for nascent experiments in tactical urbanism-small gestures that could adjust how we experienced the city. We got lucky and found an amazing group of artists, designers, writers, and activists interested in having these conversations with us. ${ }^{6}$ We tasked ourselves with trying to come up with an endless series of actions, interventions, and events that could shift or modulate our perspective on our city. We called ourselves Broken City Lab because we planned to take on self-initiated artistic "experiments" that looked at generosity, empathy, and criticality as the core components in the creative activity we would foster in public spaces.

Our projects started small and we borrowed ways of working from other disciplines like ethnography and geography and mixed them in with our artistic practices. We recorded each other as we moved through the city, using walking, mapping, and photographic documentation as some of our core tools. We talked at length, reviewing where we went to pinpoint the places that most urgently captured our collective attention, and we found pieces of infrastructure that seemed ripe for intervention. In each action, we found ourselves encountering a dissonance with an existing situation and seeing those as generative sites for creative intervention.

One of our earliest projects looked to the city's fleet of buses as rolling public spaces. We noticed the advertisements lining their interiors acted as captions for observing the city while in motion. We wondered if we could introduce a different conversation and spark some momentary dissonances with the expectations the public had for that kind of public space. We worked with the city's transit authority to secure 100 spaces and then started asking members of the public to contribute new captions to the city in a project called, Text InTransit (2009). The submissions we received ranged from poetry to playful descriptions to critical interrogations, and we worked to install them across the entire fleet. While a modest intervention, this project opened up our understanding of how a plurality of different imaginations for a public space could politically and poetically activate an everyday experience.

As our projects continued to develop and grow, we continually shifted between works that tried to capture a particular moment or sentiment in the life of the city and works that opened up new opportunities for public participation. In all cases, our projects stemmed from a sense of frustration or disagreement with something in the city-in short, a shared antagonism-and we looked at either the form or the content as a host for building agency through creative action. When we projected a series of messages onto a building on Windsor's waterfront, legible across the river in downtown Detroit, for Cross-Border 
Communication (2009), we did it because we could not resolve the disconnection between our two communities. When we invited artists and designers from across the province to our Storefront Residencies for Social Innovation (2010), we wanted to interrogate the expectations the community held for vacant spaces in the downtown core. When we wrote a creative textbook for self-study on How to Forget the Border Completely (2011), we worked to imagine a future built around how we wanted to use international public spaces to bring communities together.

Across all of these projects, we worked from the point of tension with the city we encountered, whether in physical space or through affective sensibilities. Sometimes we made demands, other times we asked questions, and still other times, we simply tried to jump-start a conversation we felt was missing in our community. Our dissatisfaction and, at times, outright conflict with the status quo generated an enormous field for creative intervention. In this way, we learned to develop our agency as a potent modulator of social experiences and interactions that could work from an interest in conflict rather than with an aim to resolve it. That sensibility is what we worked to foster through every one of our projects.

\section{Infrastructures for Collaboration}

As an extension of the one-off projects we did with Broken City Lab, in 2012, we opened Civic Space, a storefront workshop, gallery, and community event space. As a temporary social and physical infrastructure, we wanted it to be responsive in a way that could activate people and their creative inclinations towards a gradual shift in their experiences of the city. For two years, Civic Space looked at emerging artists, designers, and hackers as emerging community leaders. It aimed to stake a claim on a more creative future for the city, driven by collaboration and community-run infrastructure.

Through Civic Space, over two years, we hosted a range of artist residencies, community meet-ups, and peer-to-peer education initiatives based on an iterative process of observational and dialogical community research and public programming. Underwriting these activities was a commitment to working from a disagreement with a particular social, infrastructural, or educational reality we saw in our community. Public workshops drew a broad range of people together to learn about topics such as forgotten local architecture, critical design, and radical screen printing. Participatory projects allowed people to create temporary text installations across the city, get free tattoos of symbols and slogans from the region, and nominate neighbours for a series of "best of" awards. The form of the projects ranged from confrontational to convivial, but at the core of each of them was an aim to work in conflict with existing circumstances. In some instances, we took the lead, but most often, we acted as hosts for projects from community members and visiting artists. This process allowed us to continually shift the agency within a project from ourselves to the community. We set a frame through Civic Space, and the needs, desires, and imaginations of the 
community members filled it in. Our efforts to work in conflict became a platform for the community to enact their own creative modulations against a set of existing circumstances of everyday life.

Civic Space was also the starting point for a longer and larger project that similarly explored infrastructure as a site for artistic invention, though from a different relationship to the community in which it operated. While many of the projects we worked on in Broken City Lab were focused on the community in which we lived, the Neighbourhood Time Exchange focused on an entirely different community.

First launched in Philadelphia in 2014-15 and then in Prince George, BC in 2016-17, the Neighbourhood Time Exchange residency operated as a temporary artist-in-residence and community engagement project. The residency's framework positioned people asking for community change at the heart of the project. This also meant that rather than leading the project ourselves as community "insiders," as we did so often in other Broken City Lab projects, we were "outsiders" and relied on other local community members to take the lead on many aspects of the project. The Neighbourhood Time Exchange drew from the model of a time exchange, wherein time operates as a currency, allowing people to exchange goods and services outside of capitalist financial abstractions. For the Neighbourhood Time Exchange, artists participated in a residency in which for every hour they spent on a studio project of their choosing, they provided an hour of volunteer service back to the neighbourhood.

The invented infrastructure of the Neighbourhood Time Exchange allowed two important things to happen. First, the artists were no longer expected to solve any problems or fix any issues through the symbolic space of their artwork. They could simply work on a project in their studio that may or may not have anything to do with the context of the neighbourhood. Second, community members from the neighbourhood, whether individuals or non-profit organizations, got to ask for what they actually needed and the artists helped. We selected artists from an open call, where local community representatives made the final decisions on which artists were invited to the residency based on interviews and group discussions. Through a multi-stage interview process with stakeholders that ranged from partnering organizations to community members to local service organizations to artist groups, we collaboratively determined the focus for engagement and participation.

It was perhaps an overly simplistic fix, with imperfect results to be sure, but it struck at the core of the challenges that are so often embedded into community-engaged artist initiatives and residencies (Davis, 2013), however well-meaning they may be. Artist residencies that aim to connect artists with disadvantaged neighbourhoods and communities can all too easily reproduce the same kinds of issues around community representation that occur across larger civic or non-profit organizations (Rossiter, 2011). At their worst, socially engaged art projects and residencies are an extractive process, where the artist gets to pull 
from the affective resources of a place - the history, the people, the experience of everyday life, while the place gets an artwork they may not have asked for and may not get to see. It is an uninteresting "exchange rate" for the community members most immediately affected by it, and it does not necessarily produce very good art either. We wanted to intervene in that space to produce a difference dynamic, something that could acknowledge the insider and outsider dynamic and yet try to work beyond it.

The kind of infrastructural project represented by the Neighbourhood Time Exchange can also host that seed of conflict or antagonism I have been working with throughout this essay. We intentionally built the project around these kinds of tensions. Its structure refused to mute or obscure the challenges of conflict and instead premised the entire operation of the project on the reality that these challenges are not just present, but a fundamental part of the situation. We saw conflict not simply as a point of disruption, but as a way to open up new possibilities, a beginning instead of an ending.

\section{Pushing Forward and Being Pushy}

Whether as a seed for action, a constant reminder, or a baseline for infrastructure, conflict and antagonism, and the agency they foster, can be a driving force in a socially engaged creative practice. For artists interested in having encounters and impacts in the social world, working to resist the easy ways into and out of projects becomes especially important. We have to create new ways to address expressions of power that are quietly and violently taking away the possibilities for being in the world together on the terms we create for ourselves.

Crucially, we must also work harder to understand injustice through dialogical research, discovery, and generative action. Using the tools that we already have at our disposal, from walking and mapping to simple conversations and in-depth interviews or pithy questionnaires, we can find out what role we can and should (or should not) play in the issues we encounter. Sometimes we need to take the lead, other times we need to be allies, and still other times we need to be witnesses. How we address any one of those roles will necessarily shift from circumstance to circumstance, but thinking about how conflict can be an opening of something meaningful will be at the core of the work ahead.

As artists, our ability to shift our sense of antagonism into a creative response is something we should cultivate and share. Let us find ways to insist on the value of difference, dissensus, and disagreement. Let us make things harder. Let us agree to always disagree. 


\section{REFERENCES}

Banaji, S. (2008). The trouble with civic: A snapshot of young people's civic and political engagements in twenty-first-century democracies. Journal of Youth Studies, 11(5), 543-560. https://doi.org/10.1080/13676260802283008

Bishop, C. (2012). Artificial hells: Participatory art and the politics of spectatorship. New York: Verso Books.

Broken City Lab. (2011). How to forget the border completely. Self-published.

Davis, B. (2013, July). A critique of social practice art. International Socialist Review, (90). Retrieved from http://isreview.org/issue/90/critique-social-practice-art

Gramsci, A. (1971). Selections from the prison notebooks of Antonio Gramsci (Q. Hoare \& G. Nowell-Smith, Trans.). New York: International Publishers.

Harney, S., \& Moten, F. (2013). The undercommons: Fugitive planning \& black study. New York: Minor Compositions.

Helguera, P. (2011). Education for socially engaged art. New York, NY: Jorge Pinto Books.

Jahn, M. (Ed.) (2012). Pro+agonist: The art of opposition. Minneapolis, MN: Walker Art Center.

Laclau, E., \& Mouffe, C. (2014). Hegemony and socialist strategy: Towards a radical democratic politics (2nd ed.). London: Verso.

Maloney, S. D., \& Miller, J. A. (2008). An act is worth a thousand words: A place for public action and civic engagement in deliberative democracy. Theoria: A Journal of Social and Political Theory, 55(117), 81-103. https://doi.org/10.3167/th.2008.5511705

Miessen, M. (2010). The nightmare of participation: [Crossbench praxis as a mode of criticality]. New York: Sternberg Press.

Rancière, J. (2010). Dissensus on politics and aesthetics (S. Corcoran, Trans.). New York: Continuum.

Rossiter, N. (2011). Autonomous education, new institutions and the experimental economy of network cultures. In P. O'Neill \& C. Doherty (Eds.), Locating the producers: Durational approaches to public art (pp. 328-337). Amsterdam, NL: Valiz.

Thompson, N. (2015). Seeing power: Art and activism in the 21st century. Brooklyn, NY: Melville House Publishing. 


\section{ENDNOTES}

1. For an expanded but still accessible discussion of this idea, see (Miessen, 2010).

2. While l've offered a few examples from political philosophy here, there are a lot more reference points to these ideas that are worth exploring, in particular, because of their relationship or framing of conflict, antagonism, and the political as a core part of creative practice. For some starting points, see (Bishop, 2012; Jahn, 2012; Rancière, 2010; Thompson, 2015).

3. See the Guardian's summary of the Hong Kong protests up to mid-October 2019 for more information at https://www.theguardian.com/world/2019/oct/06/a-battle-for-the-soul-of-thecity-why-violence-has-spiralled-in-the-hong-kong-protests.

4. See the New York Times' coverage of Extinction Rebellion's tactics in 2019 at https:// www.nytimes.com/2019/10/08/world/europe/extinction-rebellion-london-greta.html.

5. See www.brokencitylab.org for more information on our collective and examples of our projects.

6. The core members of Broken City Lab, in addition to me and Danielle, for many of our projects were Hiba Abdallah, Josh Babcock, Michelle Soulliere, Cristina Naccarato, Rosina Riccardo, Kevin Echlin, and Sara Howie. 